\title{
Length-based indicators for the management of sport fishery in Yucatan, Mexico
}

\author{
Jorge A. López-Rocha ${ }^{1,2}$, Laura Vidal-Hernández ${ }^{1}$ \& Arturo Bravo-Calderón ${ }^{1}$ \\ ${ }^{1}$ Unidad Multidisciplinaria de Docencia e Investigación, Facultad de Ciencias \\ Universidad Nacional Autónoma de México, Sisal, Yucatán, México \\ ${ }^{2}$ Laboratorio de Análisis Espacial de Zonas Costeras \\ Universidad Nacional Autónoma de México, Sisal, Yucatán, México \\ Corresponding author: Laura Vidal-Hernández (laurae.vidal@ciencias.unam.mx)
}

\begin{abstract}
Sportfishing is an activity of increasing popularity that involves a large number of users and high levels of fishing effort. In Yucatan, most of the target species in sport fishing are the same as those of commercial fisheries. However, there is no record of fishing effort or catch volumes. Thus the impact of sport fishing on these populations is unknown. This study analyzes the catches made by users of sport fisheries of nine species (Epinephelus morio, Haemulon plumieri, Seriola dumerili, Lutjanus synagris, Ocyurus chrysurus, Calamus bajonado, Sphyraena barracuda, S. guachancho and Mycteroperca bonaci) through length-based indicators. Samples of species' sizes were obtained from the catches made during 10 fishing tournaments held in Yucatan's three-port towns (Sisal, Yucalpeten, and Telchac) between 2015 and 2016. The catch variables that were evaluated included: the number of mature individuals $P_{\text {mat }}$, optimal length $P_{\text {opt }}$, and the number of megaspawners $P_{\text {mega. }}$. Length measures were derived from 1,252 individuals. Only H. plumieri, L. synagris, and $S$. guachancho exhibited sustainable indicator values, while E. morio and C. bajonado demonstrated extremely low values. In most species, sport fishing affects a high proportion of juveniles. The results suggest that sportfishing contributes to the fishing pressure of a species and commercial fishing, due to the capture of juveniles of economically important fish. It is essential to establish a systematic monitoring method of such activities and increase the priority level of the evaluation and management of this fishery.
\end{abstract}

Keywords: recreational fishing; limited data; fishery evaluation; length-based indicator; Gulf of Mexico

\section{INTRODUCTION}

Recreational fishing is defined as that carried out on aquatic animals (mainly fish) whose capture is not the primary resource used to provide the basic nutritional needs of an individual and where the product is generally not sold or traded in domestic, black, or exported markets (FAO, 2008). When such an activity is performed to participate in tournaments, it is called sport fishing.

Examples of coastal sport fisheries worldwide indicate that this is an activity of increasing importance (Ihde et al., 2011; Font \& Lloret, 2014; Tunca et al., 2016; Hyder et al., 2018) involving a large number of users and consequently high levels of fishing effort (Cowx, 2002; Pitcher \& Hollingworth, 2002), which approximates the fishing effort of commercial fishing (Coleman et al., 2004; Cooke \& Cowx, 2006). Therefore, in the absence of adequate control measures, sportrecreational fishing also has multiple biological effects on exploited species, ecological effects on the aquatic ecosystems in which it is carried out (McPhee et al., 2002; Coleman et al., 2004; Cooke \& Cowx, 2004, 2006; Lewin et al., 2006) and socioeconomic effects on the communities in which it is developed (Steinback et al., 2004; Lloret et al., 2008).

Recreational fishing has ample development potential in the Gulf of Mexico. Approximately 23 million recreational fishing trips from the USA (31\%) were carried out in the northern region of the Gulf in 2009 (NMFS, 2010). While in the southeast region of the Gulf of Yucatan, there is no statistical data regarding the activity or systematic studies of any kind. There is no official procedure to monitor the results of fishing tournaments, record biological data of fisheries, or ensure follow-up of rules established by the official

Corresponding editor: Alejandra Volpedo 
standard NOM-017-PESC-1994 or by the National Fishing Chart (DOF, 2018). According to the latest official national data from CONAPESCA (2017), 55\% of recreational fishing permits are issued in Pacific Mexican states, $21 \%$ are issued in the Gulf of MexicoCaribbean coastal and inland water states, and $23 \%$ are obtained online from USA territories (i.e., San Diego, California).

Leisure and sport fishing is the third most important recreational activity on the coast of Yucatan (García-de Fuentes et al., 2011) and is practiced freely or during tournaments in marine and estuarine areas throughout the year, mainly from June to September. Various fishing techniques are practiced: bottom and middle water line or angling, jigging, trolling, and spearfishing in marine waters; flyfishing and line from shore. In the last decade, both the number of marinas and service providers associated with this activity has been increasing according to reports, mainly in tourist ports (Mexican Federation of Sport Fishing, com. per.). The number of stores for recreational fishing gear has increased six-fold in Merida's last six years, the State's capital city (there are currently 13 stores), while the number and coverage of docked yachts in Yucalpeten port have duplicated since 2005. By 2015, 1,233 docked yachts were seen in 7.88 marine ha. Currently, two harbors for recreational vessels are being constructed in Telchac, and this project is targeted to the demand of mainly foreign owners (Vidal-Hernández et al., 2017). Likewise, the activity is perceived as a productive alternative with development potential for the coastal communities that face the overexploitation of traditional commercial fishing species (DOF, 2018).

Approximately 10 to 20 sport fishing tournaments are organized by local businesses, schools, and fishing gear stores in Yucatan for national citizens to reach up to 350 participants using small fishing boats. These events can last from one to three days. These tournaments typically have three competition categories to acquire a trophy: heaviest specimen, largest specimen, and highest total catch in weight. Some tournaments specify points for particular species in which groupers (Epinephelus morio, Mycteroperca banaci), snappers (Lutjanus synagris, Ocyurus chrysurus), crevalle jack (Caranx hippos), great barracuda (Sphyraena barracuda), great amberjack (Seriola dumerili), sierra (Scomberomorus spp.) and bonito (Sarda spp.) practically always compete (VidalHernández et al., 2017).

The lack of information to evaluate the impact of the continuous and increasing pressure of sport fishing on local stocks can be addressed from the perspective of the set of analysis methods called "for data-limited." The size-based indicators proposed by Froese (2004) are based on the relationship between fisheries management and the theory of life history of the species, applied to the sizes of the fish that constitute the catches (Cope \& Punt, 2009). The indicators attempt to reflect the catches' sustainability characteristics by avoiding growth and recruitment overfishing (Cope \& Punt, 2009). These are mainly based on the size of the fish that constitute the catches, which should be exclusively composed of mature individuals and individuals with sizes whereby the highest yield of a cohort is produced; while avoiding the capture of the largest individuals or mega-spawners (Froese, 2004; Cope \& Punt, 2009). The indicators are presented in Table 1, according to Froese (2004) and Cope \& Punt (2009).

Sportfishing in Yucatan has become intensive, and its popularity continues to increase. Also, information on the fishery's ecological and social aspects is scarce, which puts its sustainability at risk. This study aims to evaluate sport fishing catches in Yucatan using the length-based indicators of Froese (2004), as an initial approach to this fishery to obtain the necessary information to design adequate measures for use in sport fishery management.

\section{MATERIALS AND METHODS}

\section{Study area}

The study area is located in the marine sections of Sisal, Yucalpeten, and Telchac ports in the northwest Yucatan Peninsula (Fig. 1), which is part of the extended continental shelf north of the Yucatan Peninsula known as Campeche Bank. This area is characterized by a slightly steep slope (Piñeiro \& Giménez, 2001).

The Campeche Bank has an area of approximately $129,499 \mathrm{~km}^{2}$, bounded by the $200 \mathrm{~m}$ isobath and the coastline. The substrate is characterized by sediments consisting of variable proportions of limestone, mud, sand, and shells, in addition to some irregularities formed by cays and coral reefs (García, 1980). An element of marked influence in this region is the upwelling that occurs in the eastern portion of the platform's slope, which favors primary production (Piñeiro \& Giménez, 2001).

The coastal zone of Yucatan integrates 16 fishing communities, and in just two decades, the number of fishers has tripled, and the number of small-scale fishing vessels has doubled (Fraga, 2004). In recent years, sport fishing in this region has become increasingly popular (CONAPESCA, 2017; VidalHernández et al., 2017; Poot-López et al., 2018), especially to visitors from abroad that are attracted to recreational fishing in coastal communities of Yucatan (Aguilar-Cordero et al., 2012). 


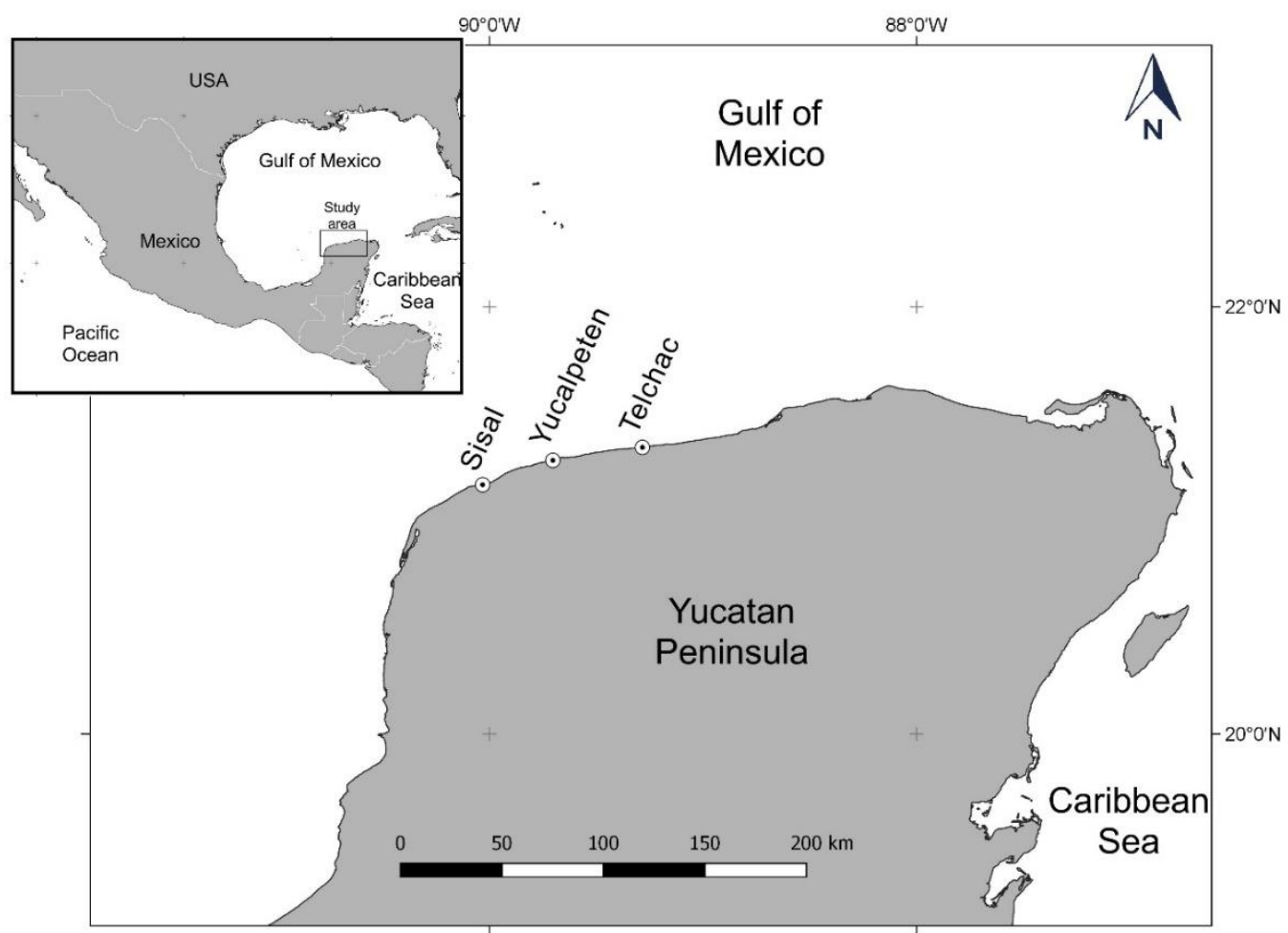

Figure 1. Study area. Location of the three ports in which the catches of sport fishing tournaments were sampled, on the northern coast of the Yucatan Peninsula, Mexico.

\section{Data collection}

Catch samples were collected from 10 (five in 2015 and five in 2016) tournaments in Sisal, Yucalpeten and Telchac ports along the northwest coast of the Yucatan Peninsula (Fig. 1) during two seasonal vacations (April and July) from 2015 to 2016 (periods in which the fishing tournaments take place). Since there are no official monitoring strategies for leisure or sport fishing activities, the only current non-official but an organized way to register landings is during tournaments.

Catch samples were obtained from fishing tournaments under a context of family-event competition; fishing was performed using hook and line and, less frequently, by trolling in sites with depths less than 20 $\mathrm{m}$. Boats and engines were generally the same as those used by small-scale fleet fishers from the fishing port (boats less than $7.62 \mathrm{~m}$ in length and containing an outboard motor), most of which $(90 \%)$ were rented from local fishers.

Samples were taken between 06:00 and 14:00 h. All catches made by participants that were judged during the tournaments were recorded, and most catches that did not enter into the contest were also recorded. However, approximately ten percent of the total catches made during the events were not recorded since they were released, consumed, or hidden for trade purposes.
The total length (TL) of each individual was measured with a conventional ichthyometer with a $\pm 1 \mathrm{~cm}$ precision. Specimens were identified using fish guides of the Gulf of Mexico developed by Hoose \& Moore (1977) and Fisher (1978).

\section{Data analysis: length-based indicators}

To evaluate sport fishing catches in Yucatan, the lengthbased indicators were applied (Froese, 2004; Cope \& Punt, 2009) (Table 1), using the species' lengthfrequency distributions caught in the fishing tournaments.

Length frequency distributions were made for each of the species captured, encompassing all seasons and ports. A minimum sample criterion of at least 30 specimens per species $(\mathrm{n} \geq 30)$ to ensure a good representation of the size distribution of the catches was established and proceed with the estimation of the indicators. When the minimum sample criterion was met, we proceeded to calculate the indicators by species per location.

Nine species were included in the analysis: red grouper Epinephelus morio, white grunt Haemulon plumieri, greater amberjack Seriola dumerili, lane snapper Lutjanus synagris, yellowtail snapper Ocyurus chrysurus, jolthead porgy Calamus bajonado, great 
Table 1. Length-based indicators (Froese, 2004; Cope \& Punt, 2009) used to analyze the impact on nine species caught in sport fishery tournaments on the northern coast of the Yucatan Peninsula, Mexico. $P_{L}=$ catch proportion of the length class $L ; L_{m}$ : length at first maturity; $L_{\max }$ : maximum length; $L_{\text {opt }}$ optimal length.

\begin{tabular}{l}
\hline \multicolumn{1}{c}{ Indicator } \\
\hline Pmat. Proportion of sexually mature individuals from total catches measured as the \\
percentage of mature specimens from the catch. The objective is to allow $100 \%$ of \\
fish to spawn at least once before being caught to rebuild and maintain healthy \\
breeding populations $(P m a t=1)$. \\
$P_{\text {opt. }}$ The proportion of individuals of the size that maximizes the yield from total \\
catches, measured as the percentage of individuals captured within $\pm 10 \%$ of the \\
optimum length. The objective is to capture $100 \%$ of the fish within $\pm 10 \%$ of the \\
optimum length $\left(P_{\text {opt }}=1\right)$. \\
Pmega. The proportion of individuals to ensure the conservation of sexually mature \\
individuals of the largest sizes, mega-spawners. It is measured as a percentage of large \\
fish in the catch: fish of a size larger than the optimum length plus $10 \%$. Values of 30 \\
to $40 \%$ of mega-spawners reflect a healthy age structure $\left(P_{\text {mega }}=0.3-0.4\right)$. \\
$P$ Pobj. Sum of the three previously defined indicators. Values between 1 and 2 \\
represent selectivity patterns that follow the sustainability recommendations of Froese \\
(2004).
\end{tabular}

barracuda Sphyraena barracuda, guachanche barracuda Sphyraena guachancho and black grouper Mycteroperca bonaci.

The estimated proportion of the catches in each length interval $(P L)$ was calculated by fitting the logistic model to the accumulated length-frequency distributions, using the formula: $P L=1 /[1+\exp (a-b$ $\times L)$ ], where $a$ and $b$ are parameters of the logistic model and $L$ is the length interval for which the estimate is performed. The adjustment process was performed using the least-squares criterion and Newton's nonlinear numerical method (Neter et al., 1996).

Estimates of the length at first maturity $\left(L_{m}\right)$ and of the optimum length $\left(L_{o p t}\right)$ were required to calculate the length-based indicators (Table 1). A bibliographic search was done for estimates of $L_{m}$ and $\mathrm{L} \infty$. Parameters $K$ and $M$ of each species were used to calculate $L_{o p t}$ according to Beverton (1992) as $L_{\text {opt }}=\mathrm{L}_{\infty}[3 / 3+(\mathrm{M} /$ $\mathrm{K})$ ]; where $L_{\infty}=$ asymptotic length, a parameter of the Von Bertalanffy growth model $(\mathrm{cm}) ; M=$ natural mortality rate $\left(\mathrm{yr}^{-1}\right)$; and $K=$ growth coefficient of the Von Bertalanffy growth model $\left(\mathrm{yr}^{-1}\right)$.

When no parameter was identified, it was estimated through empirical relationships proposed by Froese \& Binohlam (2000) and Then et al. (2015); $L_{\infty}$ from $L_{\max }$ : $\log L_{\infty}=0.044+0.9841 * \log \left(L_{\max }\right) ; L_{\mathrm{m}}$ from $L_{\infty}: \log$ $L_{\mathrm{m}}=0.8979 * \log L_{\infty}-0.0782 ; L_{\mathrm{opt}}$ from $L_{\infty}: \log L_{\mathrm{opt}}=$ $1.0421 * \log L_{\infty}-0.2742$; and $M$ from $t_{\max }: M=4.899$ $\left.t_{\max }{ }^{-0.916}\right)$. For the parameters documented in fork length (FL), total length transformations (TL) were carried out through the form: $\mathrm{TL}=a+b$ (FL), where parameters $a$ and $b$ were obtained from Fishbase (Froese \& Pauly, 2019). Parameters derived from literature and parameters estimated by empirical relationships are shown in Table 2.

Additionally, the following indicators were calculated: $L_{\max 5 \%} / L_{\infty}$ and $L_{95 \%} / L_{\infty}$ where $L_{\max 5 \%}=$ mean length of largest $5 \%$ and $L_{95 \%}=95^{\text {th }}$ percentile of the length distribution. The reference point in both cases is $>0.8$, which is related to the conservation of the largest individuals. Indicators were also calculated about the conservation of immature individuals: $L_{25} \%$ / $L_{\mathrm{m}}, L_{\text {mean }} / L_{\mathrm{m}}$ and $L_{\mathrm{c}} / L_{\mathrm{m}}$, where $L_{25 \%}=25^{\text {th }}$ percentile of the length distribution and $L_{\text {mean }}=$ mean length. Values $>0.3$ are expected in the first indicator, while values $>1$ are expected in the last two. Likewise, the $L_{\text {mean }} / L_{\text {opt }}$ ratio was calculated where $L_{\text {mean }} / L_{\text {opt }} \approx 1$ would be expected; meaning that $L_{\text {mean }}$ of the catch is predicted to be equal to the $L_{\text {opt }}$, which has been proposed as a measure to reduce the impact of fishing by allowing fish to grow before being caught (Froese $e t$ al., 2016; Fitzgerald et al., 2018).

\section{RESULTS}

The total length (TL) was obtained from 1,252 fish belonging to 22 fish species. Nine species $(1,056$ individuals) were analyzed according to the minimum data criterion to proceed with the calculation of the indicators (Table 3); $57 \%$ of measurements were made 
Table 2. Parameters for the estimation of length-based indicators from nine species caught in sport fishing tournaments in the northern coast of the Yucatan Peninsula, Mexico. $L_{m}$ : maturity length $(\mathrm{cm}) ; L_{\infty}$ : asymptotic length $(\mathrm{cm})$ and $k$ : growth coefficient $\left(\mathrm{yr}^{-1}\right)$, both of the Von Bertalanffy growth model; $M$ : natural mortality rate $\left(\mathrm{yr}^{-1}\right)$. ${ }^{*}$ Standard or fork lengths transformed to the total length.

\begin{tabular}{|c|c|c|c|c|c|c|}
\hline Species & Location & Reference & $L_{\mathrm{m}}$ & $L_{\infty}$ & $k$ & $M$ \\
\hline \multirow[t]{3}{*}{ Epinephelus morio } & Campeche Bank & Brulé et al. (1999) & 50.9 & & & \\
\hline & Cuba & Rodríguez (1994) in DOF (2014) & & 82.7 & 0.21 & \\
\hline & Campeche Bank & Burgos \& Defeo (2004) & & & & 0.24 \\
\hline \multirow[t]{2}{*}{ Haemulon plumieri } & Cuba & García-Cagide (1987) in Fishbase (2019) & $18.4 *$ & & & \\
\hline & Yucatan & Domínguez-Viveros \& Ávila-Martínez (1996) & & 41.7 & & \\
\hline \multirow[t]{2}{*}{ Seriola dumerili } & Carolina-Florida & Harris et al. (2007) & $74.7 *$ & $142.8^{*}$ & 0.28 & \\
\hline & Adriatic Sea & Kožul et al. (2001) & & & & 0.3 \\
\hline \multirow[t]{3}{*}{ Lutjanus synagris } & Cuba & Rodríguez-Pino (1962) in Fishbase & 20.2 & & & \\
\hline & Yucatan & Torres-Lara \& Salas-Márquez (1990) & & & 0.28 & 0.36 \\
\hline & & Froese \& Binohlan (2000) & & 41 & & \\
\hline \multirow[t]{2}{*}{ Ocyurus chrysurus } & Southeast United States & Muller et al. (2003) & 20.9 & & & 0.2 \\
\hline & Yucatan & Mexicano-Cíntora (1999) & & $59.05^{*}$ & 0.22 & \\
\hline \multirow[t]{2}{*}{ Calamus bajonado } & Florida & Burton et al. (2017) & & 73.7 & 0.14 & 0.32 \\
\hline & & Froese \& Binohlan (2000) & 39.7 & & & \\
\hline \multirow[t]{2}{*}{ Sphyraena barracuda } & Caribbean Sea & Bent-Hooker (2006) & 66.7 & 153.3 & 0.12 & \\
\hline & & Then et al. (2015) & & & & 0.21 \\
\hline Sphyraena guachancho & & Froese \& Binohlan (2000) & 51.2 & 97.8 & & \\
\hline \multirow[t]{3}{*}{ Mycteroperca bonaci } & Florida & Crabtree \& Bullock (1998) & & 130.6 & 0.19 & \\
\hline & & Fishbase (2019) & 67.7 & & & \\
\hline & & Then et al. (2015) & & & & 0.38 \\
\hline
\end{tabular}

Table 3. The number of individuals measured from analyzed and non-analyzed fish species of samples taken during sport fishing tournaments along the northern coast of the Yucatan Peninsula, Mexico.

\begin{tabular}{|c|c|c|c|c|}
\hline Species analyzed & Common name & Total & 2015 & 2016 \\
\hline Epinephelus morio & Red grouper & 369 & 104 & 265 \\
\hline Haemulon plumieri & White grunt & 249 & 146 & 103 \\
\hline Seriola dumerili & Greater amberjack & 104 & 75 & 29 \\
\hline Lutjanus synagris & Lane snapper & 82 & 82 & 0 \\
\hline Ocyurus chrysurus & Yellowtail snapper & 78 & 48 & 30 \\
\hline Calamus bajonado & Jolthead porgy & 57 & 36 & 21 \\
\hline Sphyraena barracuda & Great barracuda & 51 & 23 & 28 \\
\hline Sphyraena guachancho & Guachanche barracuda & 35 & 0 & 35 \\
\hline Mycteroperca bonaci & Black grouper & 31 & 10 & 21 \\
\hline \multicolumn{5}{|l|}{ Species not analyzed } \\
\hline Epinephelus spp. & Grouper & 49 & & \\
\hline Caranx spp. & Jack & 23 & & \\
\hline Calamus calamus & Saucereye porgy & 23 & & \\
\hline Lutjanus spp. & Snapper & 23 & & \\
\hline Caranx hippos & Crevalle jack & 22 & & \\
\hline Cynoscion nebulosus & Spotted weakfish & 20 & & \\
\hline Caranx latus & Horse-eye jack & 7 & & \\
\hline Scomberomorus maculatus & Atlantic Spanish mackerel & 7 & & \\
\hline Epinephelus adscensionis & Rock hind & 6 & & \\
\hline Balistes spp. & Triggerfish & 5 & & \\
\hline Gerres cinereus & Yellowfin mojarra & 4 & & \\
\hline Cynoscion spp. & Weakfish & 4 & & \\
\hline Sarda sarda & Atlantic bonito & 3 & & \\
\hline
\end{tabular}

in Yucalpeten, 28\% in Sisal, and 15\% in Telchac. Of the analyzed species, Epinephelus morio and Haemulon plumieri represented $59 \%$ of the total number of individuals (35 and 24\% respectively). Yucalpeten samplings were mostly integrated with E. morio, while Telchac and Sisal were mostly composed of H. plumieri. 


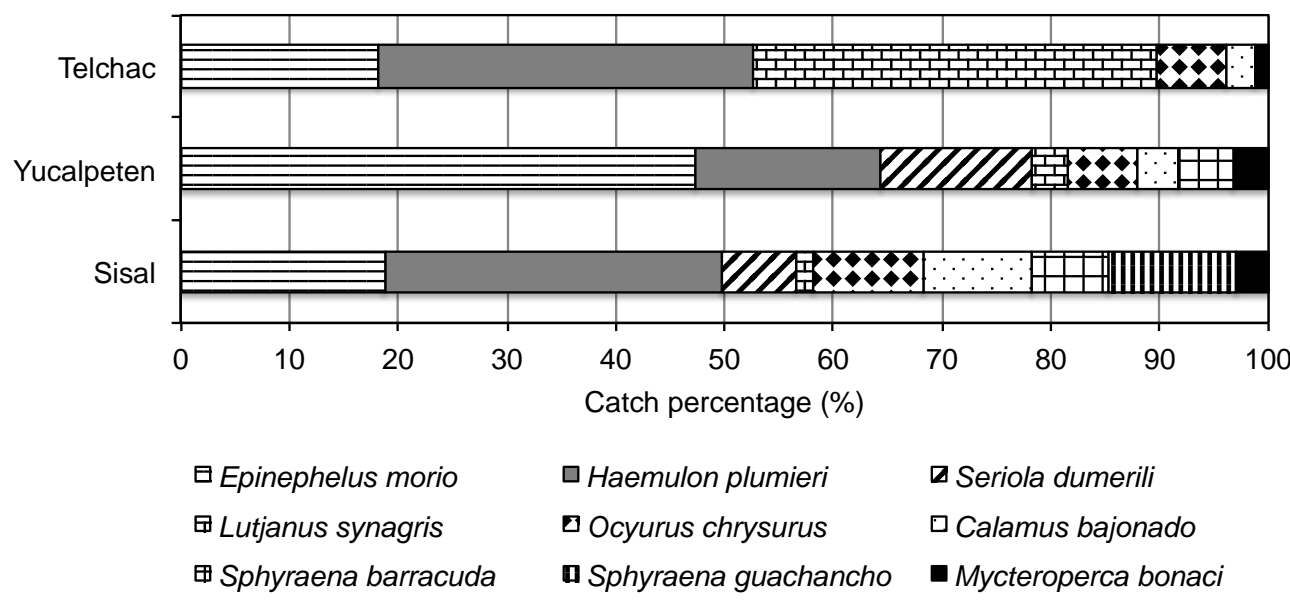

Figure 2. Catch percentage by port in sport fishing tournaments in the northern coast of the Yucatan Peninsula, Mexico.

Sphyraena barracuda or Seriola dumerili were not recorded in Telchac; on the other hand, Sisal was the only port where specimens of Sphyraena guachancho were recorded (Fig. 2).

Two categories of species could be differentiated according to their mean length $L_{\text {mean }}$. Those of relatively large $L_{\text {mean }}$ between 59.3-85.6 cm TL, among which S. barracuda, S. dumerili, S. guachancho, and Mycteroperca bonaci were observed; and another group with a relatively small $L_{\text {mean }}$ between $26.1-33 \mathrm{~cm}$ TL which included species $H$. plumieri, Lutjanus synagris, Ocyurus chrysurus, E. morio, and Calamus bajonado. Table 4 presents the values of the six calculated ratios for each species. Two species $(S$. barracuda and $S$. guachancho) obtained optimal values in the six indicators. On the other hand, for three species (E. morio, C. bajonado, and M. bonaci), only one indicator was above the reference point.

The results demonstrate that only $H$. plumieri, $L$. synagris, and $S$. guachancho present values of $P_{\text {mat }}$ $(>90 \%)$, which approximates the objective of $100 \%$, indicating that fishing almost entirely affects adult individuals in these three species. S. dumerili, $O$. chrysurus, $S$. barracuda, and $M$. bonaci displayed mean values between 29 and $63 \%$ of $P_{m a t}$, indicating that a significant proportion of the catches of these species are juveniles. However, the proportion of mature individuals in the catches of $C$. bajonado and E. morio were extremely low $(<2 \%)$, suggesting that all catches from both species were juveniles (Fig. 3).

Concerning $P_{\text {opt }}$, the highest percentages also occurred in S. guachancho (61\%), H. plumieri (48\%) and L. synagris $(39 \%)$, although these are relatively high values in comparison with the other species, these values are still far from the $100 \%$ objective of the catches within $\pm 10 \% L_{\text {opt }}$. Catches of the other species were far from optimal length; they were all observed to be between 0 to $14 \%$ of $P_{\text {opt }}$ (Fig. 3).

With regards to $P_{\text {mega }}$, only $S$. guachancho presented a relatively high value of $P_{\text {mega }}(21 \%)$, indicating a moderate capture of large individuals. In the rest of the species, $P_{\text {mega }}$ values varied from 0 to $7 \%$, indicating that sportfishing does not affect individuals of greater size, which is considered mega-spawners (Fig. 3).

The $P_{\text {obj }}$ values showed that only three species, $H$. plumieri, L. synagris, and $S$. guachancho had values higher than 1 , indicating that sportfishing catches of these species constitute a range of sizes that meet the sustainability requirements of the indicators. On the other hand, values of $P_{\text {obj }}$ in $C$. bajonado and E. morio were extremely low; the remaining four species obtained intermediate values of $P_{o b j}$ (Fig. 3). Figure 4 provides a comparative summary of the four indicators.

\section{DISCUSSION}

There is increasing evidence that sport fishing can lead to a decrease in the fish population, contributing to the fisheries' decline and affecting ecosystems when fish mortality is high and selective exploitation is intense (Cooke \& Cowx, 2004; Wolf-Christian et al., 2006). Our results highlight that a large portion of fish catches by users of the sport fishery in Yucatan comprise a high proportion of juveniles. Only three (Haemulon plumieri, Lutjanus synagris, and Sphyraena guachancho) out of the nine analyzed species presented indicator values close to the objective (Froese, 2004); also important because information on sport fishery in the region is very scarce, in addition to overlapping with commercial fishing species.

Methods that can be used to evaluate fishery sustainability when only limited data exits provide 


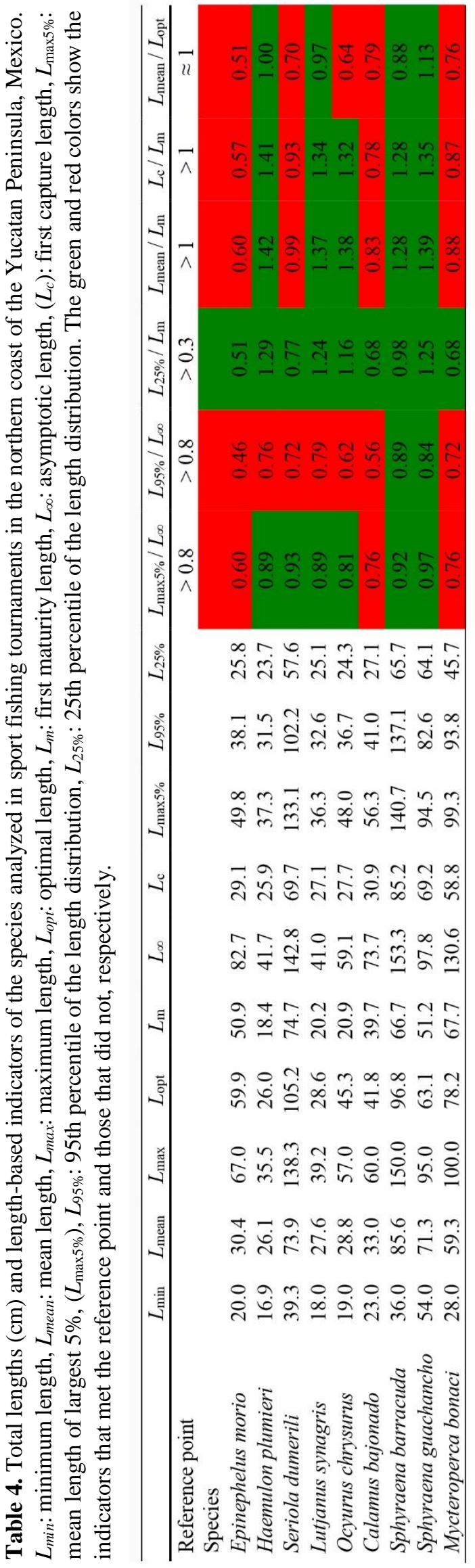

suitable tools that can guide management actions focused on maintaining sustainable yields over time (Apel et al., 2013). Although it is clear that the lengthfrequency distributions obtained from the sportfishing catches do not necessarily reflect the size structure of the entire population vulnerable to fishing, it does represent the size structure that is being pressured by sport fishing, which was the objective of this work. It is necessary to point out that most retained individuals (close to $90 \%$ of those caught, competing or not) were included in the analysis; thus, there was no bias due to competing sizes. In this sense, if any size structure were biased towards larger sizes, as could be expected from sport fishing competing catches, the indicators' values would tend to move further away from the optimum, especially $P_{\text {mega }}$. However, due to the mode in which sport fishing is carried out in Yucatan, it is highly probable a high overlap in size range captured by sport fishing and small-scale fishing.

Although precise detection of patterns in the indicators requires medium and long-term time scales ( $>5$ years), when there is a piece of lack information, the use of length-based indicators, such as those applied in this study, can provide valuable information which could be contributory to the first management measures of the fishery. Also, the limitation to make final recommendations must be recognized, as it is probable that changes in size structures and the magnitude of catches will occur over time, therefore the values of the proportions of the indicators will vary in the same way. There are not recent registers that sport fishing activities in the State have changed (L. Vidal, com. pers.). Despite this limitation, the information provided in this article represents a starting point in understanding the effect of sport fishing on fish populations in Yucatan. Moreover, from this, suggest continuous monitoring of the size structure of sport fishing, not only with the participation of fisheries administration and academic research institutions but also of fishers, sport-fishermen, tournament organizers and the general public, incorporating these actions within a framework of citizen science, such as suggested by Pita et al. (2020).

The study results allowed species to be categorized into three groups according to the indicators' values. The first group was composed of the species $H$. plumieri, L. synagris, and $S$. guachancho, with values of $P_{o b j}>1$ indicating that members of this group can be considered as being sustainably fished. A second group with intermediate values of $P_{o b j}(0.38-0.71)$ was composed of the species Mycteroperca bonaci, Ocyurus chrysurus, Sphyraena barracuda, and Seriola dumerili; and the third group was composed of Calamus bajonado and Epinephelus morio and exhibited extreme- 

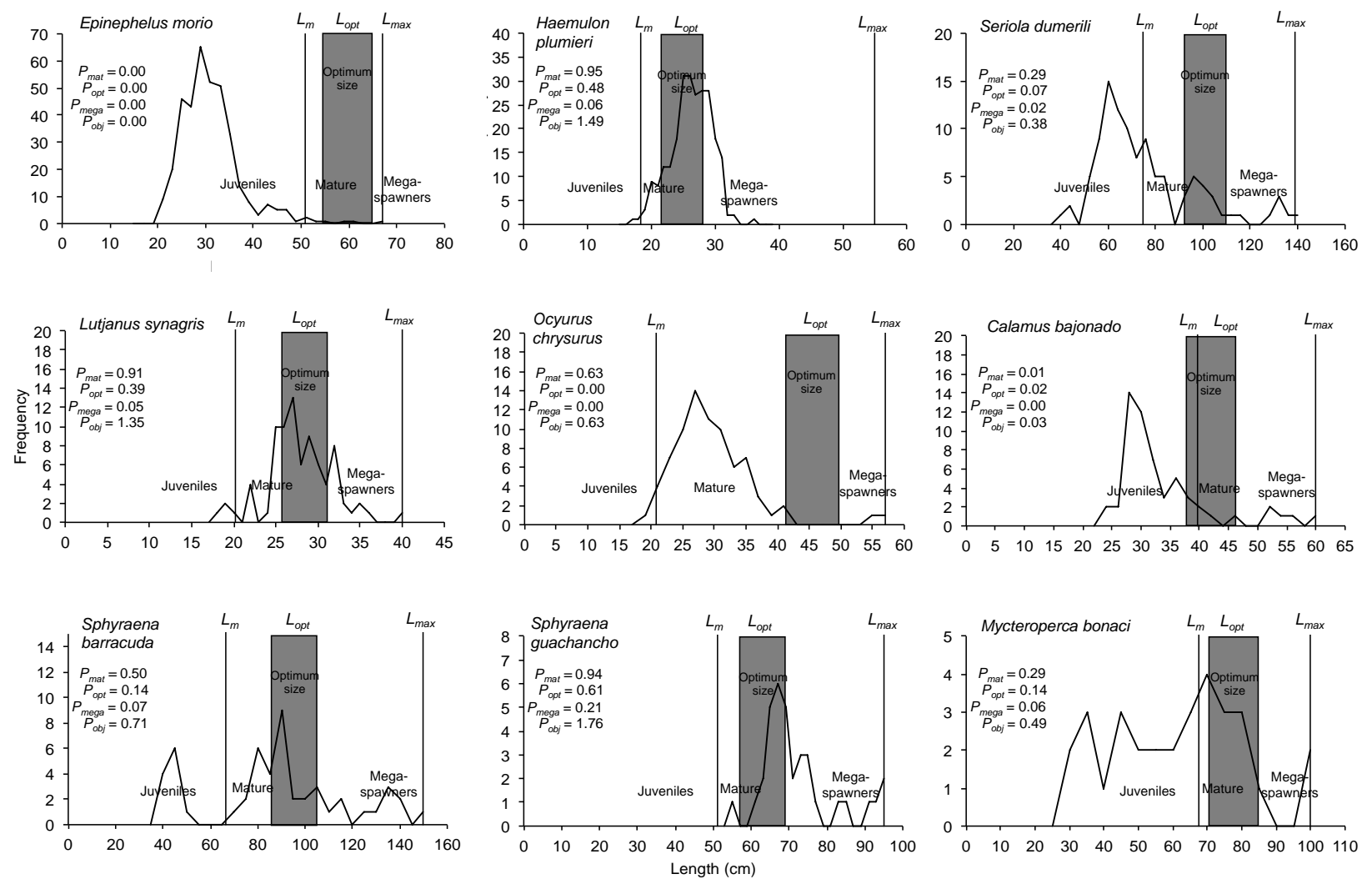

Figure 3. Length - frequency distributions of the species analyzed of the sportfishing tournaments on the northern coast of the Yucatan peninsula, Mexico. $L_{m}$ : length at first maturity; $L_{\text {opt }}$ : optimal length; $L_{\max }$ : maximum length.

ly low $P_{o b j}$ values $(0.00-0.03)$. It shows that it is crucial to consider these differences in sport fishing management actions, such as in the issuance of fishing permits or encouraging or discouraging sport fishing of certain species.

Guachanche barracuda $S$. guachancho exhibits high values in all indicators. Unlike $H$. plumieri and $L$. synagris, this species is not associated with the red grouper - black grouper fishery, which is the largest fish fishery of the Yucatan Peninsula (DOF, 2014). Thus, $S$. guachancho has the potential to be considered as an exclusive species of sport fishing.

Lane snapper $L$. synagris is another species that exhibited higher values of $P_{\mathrm{obj}}$; almost all of the individual catches had reached their maturity, and approximately $40 \%$ were of optimal length. However, $O$. chrysurus displayed a $P_{\text {mat }}$ value of $63 \%$, and $P_{\text {opt }}$ and $P_{\text {mega }}$ (Fig. 4) values close to zero. Values close to zero agree with the results of Poot-López et al. (2018), who found a greater proportion of immature specimens in $O$. chrysurus rather than L. synagris, in which the first catch size $\left(L_{50}\right)$ was similar to its maturity size $\left(L_{m}\right)$. Even though results in both species represented
$15 \%$ of total analyzed specimens (Fig. 2), Poot-López et al. (2018) demonstrated that catch composition varies monthly, with $L$. synagris being a key component of catches from January to April, and O. chrysurus from September to December.

Except for $S$. barracuda, a species allocated to the second and third groups, with non-optimal indicator values, found among the 33 species associated with the red grouper - black grouper fishery located in the south of the Gulf of Mexico, that is currently considered in deterioration (Monroy-García et al., 2014; DOF, 2018). Red grouper E. morio is considered as being overexploited (Burgos \& Defeo, 2004; GiménezHurtado et al., 2005). In this regard, our study suggests an inadequate selectivity pattern of sport fishery catches of M. bonaci, O. chrysurus, S. dumerili, and especially $C$. bajonado and E. morio.

The response to fishing pressure may be different in the dioecious species than in the protogynous hermaphroditic, such as M. bonaci and E. morio (Crabtree \& Bullock, 1998; Brulé et al., 1999), where the pattern of sex change plays a fundamental role (Alonzo \& Mangel, 2005). In the case of length-based 

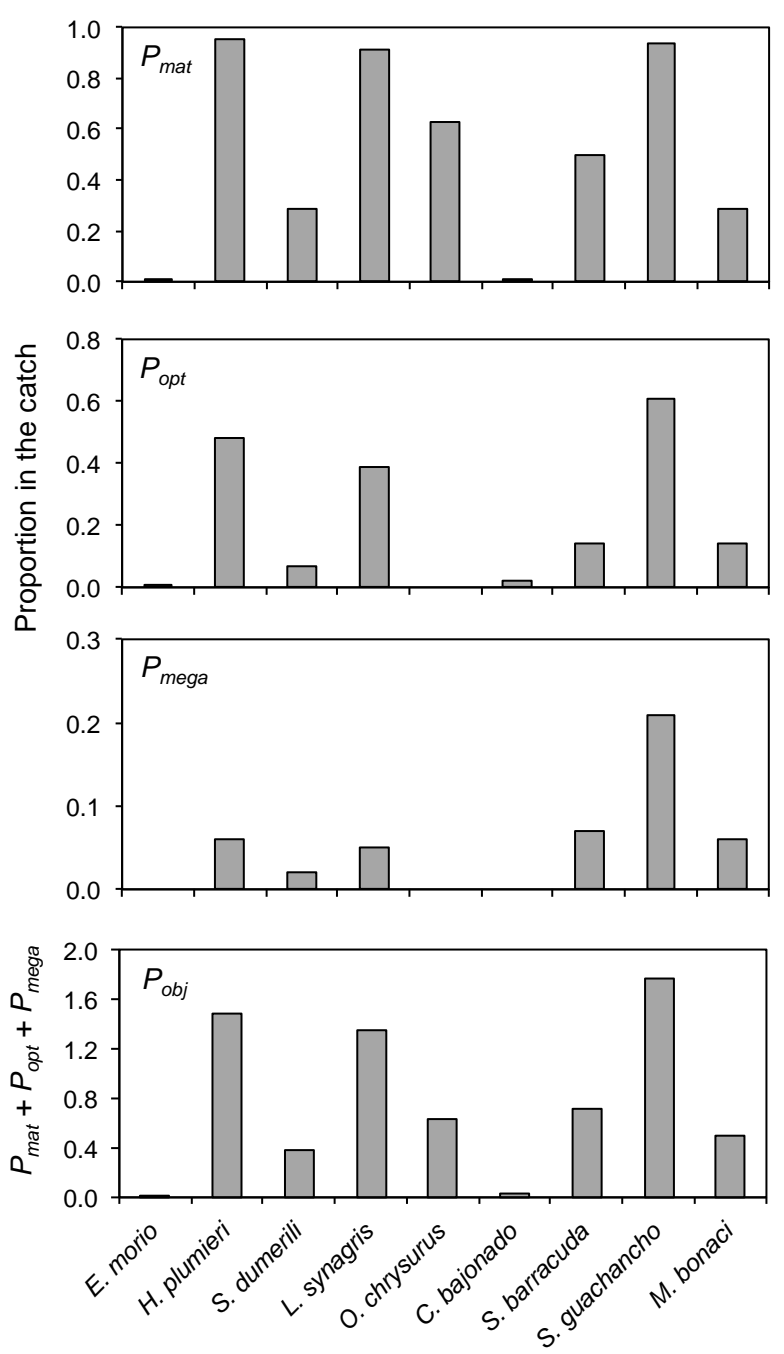

Figure 4. Length-based indicators $\left(P_{\text {mat }}, P_{\text {opt }}, P_{\text {mega }}\right.$, and $\left.P_{\text {obj }}\right)$ calculated for the nine analyzed species of the sportfishing tournaments on the northern coast of the Yucatan Peninsula, Mexico.

indicators, it is important to consider the sex and the transition size. In E. morio, the size at which females change sex occurs in a range of 41.0-85.4 cm FL, with a mean of $59.7 \mathrm{~cm} \mathrm{FL} \mathrm{(Brule} \mathrm{et} \mathrm{al.,} \mathrm{1999).} \mathrm{In} \mathrm{this} \mathrm{type}$ of species, $P_{\text {mega }}$ would be more important than $P_{\text {mat }}$. It is necessary to understand the endogenous or exogenous signals that induce sex change to comprehend how fishing impacts these populations (Alonzo \& Mangel, 2005). It is also important to recognize that the age and length of the first maturity in stocks that have been subject to overfishing may change in response to the high fishing mortality to which the stocks are subjected (Harris et al., 2001). It should be taken into account to continue evaluating or updating the estimated size of the main species at first maturity, which may be reflected in the estimation of lengthbased indicators.
The depth at which sport fishing occurs can explain the effect of sport fishing on the juveniles of most species. The large proportion of individuals with smaller sizes than $L_{m}$ and $L_{\text {opt }}$ does not necessarily mean the absence of larger specimens in the population since most of these species (i.e., groupers) are distributed by size. Juveniles are found in shallow water while adults are found in deep water (Hernández \& Seijo, 2003; López-Rocha \& Arreguín-Sánchez, 2008, 2013), suggesting that sportfishing zones are not far from the coast. The coast of Yucatan has an extensive continental platform. Hence vast distances must be traveled to reach relatively large depths. Although recreational and sport fishing is increasing, fishers do not travel far from the coast for this activity.

A particular case is the greater amberjack $(S$. dumerili), which is one of the most important leisure fishing species in the Gulf of Mexico, it is overexploited on the north of the Gulf of Mexico, and within recreational fishing activities, private boats have been identified as the sector with the highest number of catches (Diaz et al., 2005). There are no regulations for fishing of this species in Yucatan; furthermore, it is classified as an associated catch in the fisheries of red grouper - black grouper, red snapper, Atlantic Spanish mackerel, common snook and horse-eye jack from the south of the Gulf of Mexico (DOF, 2018). Of the evaluated species in this study, S. dumerili was the third most common catch, constituting $10 \%$ of total measurements. Also, of the evaluated catches, it was one of the species with the lowest indicator values, $S$. dumerili is one of the most vulnerable species to sport fishery.

Ihde et al. (2011) indicate that leisure fishing in the USA continues to grow in importance and they warn that there is a lack of successful performance-based strategies designed for commercial fishing, these authors suggest management objectives based on size and initiatives based on key stakeholders. On the coast of Yucatan, there is no record of catches or mortality estimates from leisure or sport fishing. This study, in conjunction with the study by Poot-López et al. (2018), demonstrates that more than 40 species are caught by leisure and sport fishing on the north coast of the Yucatan Peninsula.

While it is recognized that a more extended study period is desirable, to observe possible trends in the selectivity patterns, our results can now guide some measures such as: 1) excluding certain species from sport fishing such as: C. bajonado and E. morio, 2) promote the capture of $H$. plumieri and L. synagris as target species for sport fishing, with $S$. guachancho being a sport fishing exclusive species; while discouraging sport fishing of $M$. bonaci, O. chrysurus, $S$. 
barracuda and $S$. dumerili, 3) implementation of a monitoring system in sport fishing tournaments, 4) use of methods for limited data that will enable the generation of knowledge and, thus, allow records to be generated by monitoring programs, in addition to supporting the design of specific regulatory measures for species that are often captured recreationally and 5) encourage recreational and sport fishers to fish at greater depths, as well as strive to eliminate the prize category of highest total catch weight in the local tournaments, since it is for this reason mainly that fishers retain any species of small sizes. It is essential to increase the priority level of the evaluation and management of sport fishing.

\section{ACKNOWLEDGMENTS}

We thank the DGAPA-PAPIIT-UNAM with key IA302115 for funding this study of which the Project is entitled "Recreational fishing as an emerging activity on the Yucatan State: characterization and diagnosis for its management" granted to the second author. We also thank tournament organizers and sport fishers that allow us to monitor their catches and student of the eighth and ninth generation of the Bachelor in Sustainable Management of Coastal Zones (UNAM) monitoring tournaments.

\section{REFERENCES}

Aguilar-Cordero, W., Castro-Castillo, N. \& Couoh-Cab, J. 2012. El manejo del área marina y costera protegida Actam Chuleb y los beneficios económicos que genera a los usuarios del municipio de San Felipe, Yucatán, México. Estudios Sociales, 20: 125-153.

Alonzo, S.H. \& Mangel, M. 2005. Sex-change rules, stock dynamics, and the performance of spawning-perrecruit measures in protogynous stocks. Fishery Bulletin, 103: 229-245.

Apel, A.M., Fujita, R. \& Karr, K. 2013. Science-based management of data-limited fisheries: a supplement to the catch share design manual. Environmental Defense Fund, New York, 27 pp.

Bent-Hooker, H.C. 2006. Biología, ecología y pesquería de la barracuda Sphyraena barracuda (Walbaum, 1792) (Pisces: Perciformes: Sphyraenidae) en la isla de San Andrés y los cayos Bolívar y Albuquerque, Caribe colombiano. Tesis de Biología Marina, Universidad de Bogotá Jorge Tadeo Lozano, Bogotá, 81 pp.

Beverton, R.J.H. 1992. Patterns of reproductive strategy parameters in some marine teleost fishes. Journal of Fish Biology, 41: 137-160.

Brulé, T., Déniel, C., Colás-Marrufo, T. \& SánchezCrespo, M. 1999. Red grouper reproduction in the southern Gulf of Mexico, Transactions of the American Fisheries Society, 128(3): 385-402.

Burgos, R. \& Defeo, O. 2004. Long-term population structure, mortality and modeling of a tropical multifleet fishery: the red grouper Epinephelus morio of the Campeche Bank, Gulf of Mexico. Fisheries Research, 66: 325-335.

Burton, M.L., Potts, J.C., Page, J. \& Poholek, A. 2017. Age, growth, mortality and reproductive seasonality of jolthead porgy, Calamus bajonado, from Florida waters. PeerJ, 5: e3774. doi: 10.7717/peerj.3774

Coleman, F.C., Figueira, W.F., Ueland, J.S. \& Crowder, L.B. 2004. The impact of the United States recreational fisheries on marine fish populations. Science, 305(5692): 958-1960. doi: 10.1126/science. 1100397

Comisión Nacional de Pesca y Acuacultura (CONAPESCA). 2017. Tabla de permisos expedidos a nivel nacional para la pesca deportiva recreativa. [https:// datos.gob.mx/busca/permisos-de-pesca-deportiva]. Reviewed: March 21, 2020.

Cooke, S.J. \& Cowx, I.G. 2004. The role of recreational fishing in global fish crises. Bioscience, 54(9): 857859.

Cooke, S.J. \& Cowx, I.G. 2006. Contrasting recreational and commercial fishing: searching for common issues to promote unified conservation of fisheries resources and aquatic environments. Biological Conservation, 128(1): 93-108. doi: 10.1016/j.biocon.2005.09.019

Cope, J.M. \& Punt, A.E. 2009. Length-based reference points for data-limited situations: applications and restrictions. Marine and Coastal Fisheries: Dynamics, Management, and Ecosystem Science, 1: 169-186.

Cowx, I.G. 2002. Recreational fishing. In: Hart, P. \& Reynolds, J. (Eds.). Handbook of fish biology and fisheries 2. Blackwell Science, London, pp. 367-390.

Crabtree, R.E. \& Bullock, L.H. 1998. Age, growth, and reproduction of black grouper, Mycteroperca bonaci, in Florida waters. Fishery Bulletin, 96: 735-753.

Diario Oficial de la Federación (DOF). 2014. Acuerdo por el que se da a conocer el plan de manejo pesquero de mero (Epinephelus morio) y especies asociadas en la Península de Yucatán. Diario Oficial de La Federación. Secretaría de Agricultura, Ganadería, Desarrollo Rural, Pesca y Alimentación, Ciudad de México.

Diario Oficial de la Federación (DOF). 2018. Acuerdo por el que se da a conocer la actualización de la carta nacional pesquera. Diario Oficial de La Federación. Secretaría de Agricultura, Ganadería, Desarrollo Rural, Pesca y Alimentación, Ciudad de México.

Diaz, G.A., Brooks, E.N. \& Porch, C.E. 2005. Gulf of Mexico greater amberjack stock assessment. Southeast Data, Assessment, and Review (SEDAR), SEDAR9AW-05-Rev, North Charleston SC., 490 pp. 
Domínguez-Viveros, M. \& Ávila-Martínez, J.G. 1996. Diagnosis preliminar de la pesquería de chac-chi (Haemulon plumieri; Lacépède, 1802) del Banco de Campeche en base al análisis de distribuciones de frecuencias de longitudes. Proceedings of the Gulf and Caribbean Fisheries Institute, 44: 747-758.

Fisher, W. 1978. Species identification sheets for fishery and purposes. Food and Agriculture Organization, FAO, Rome.

Fitzgerald, C.J., Delanty, K. \& Shephard, S. 2018. Inland fish stock assessment: applying data-poor methods from marine systems. Fisheries Management and Ecology, 25(4): 240-252.

Font, T. \& Lloret, J. 2014. Biological and ecological impacts derived from recreational fishing in Mediterranean coastal areas. Reviews in Fisheries Science and Aquaculture, 22(1): 73-85.

Food and Agriculture Organization (FAO). 2008. Code of practice for recreational fisheries. FAO European Inland Fisheries Advisory Commission (EIFAC), Rome, 54 pp. [http://www.fao.org/docrep/012/i0363e/ i0363e00.htm]. Reviewed: March 21, 2020.

Fraga, J. 2004. Los habitantes de la zona costera de Yucatán: entre la tradición y la modernidad. In: RiveraArriaga, E., Villalobos-Zapata, G., Azuz-Adeath, I. \& Rosado-May, F. (Eds.). El manejo costero en México. Universidad Autónoma de Campeche, Campeche.

Froese, R. 2004. Keep it simple: three indicators to deal with overfishing. Fish and Fisheries, 5(1): 86-91. doi: 10.1111/j.1467-2979.2004.00144.x

Froese, R. \& Binohlan, C. 2000. Empirical relationships to estimate asymptotic length, length at first maturity and length at maximum yield per recruit in fishes, with a simple method to evaluate length-frequency data. Journal of Fish Biology, 56: 758-773.

Froese, R. \& Pauly, D. (Eds.). 2019. FishBase. World Wide Web electronic publication. [www.fishbase.org]. Reviewed: March 21, 2020.

Froese, R., Winker, H., Gascuel, D., Sumalia, U.R. \& Pauly, D. 2016. Minimizing the impact of fishing. Fish and Fisheries, 17(3): 785-802. doi: 10.1111/faf.12146

García, C. 1980. Caracterización general del Banco de Campeche. Revista Cubana de Investigaciones Pesqueras, 5(2):1-10.

García-de-Fuentes, A., Xool-Koh, M., Euán-Ávila, J., Munguía-Gil, A. \& Cervera-Montejano, D. 2011. La costa de Yucatán en la perspectiva del desarrollo turístico. Comisión Nacional para el Conocimiento y Uso de la Biodiversidad (CONABIO). Corredor Biológico Mesoamericano, Serie Conocimientos, 9: 82 pp.

Giménez-Hurtado, E., Coyula, R., Luch-Cota, S.E., González-Yáñez, A., Moreno-García, V. \& Burgos, R. 2005. Historical biomass, fishing mortality, and recruitment trends of the Campeche Bank red grouper (Epinephelus morio). Fisheries Research, 71: 267-277.

Harris, P.J., Padgett, S.M. \& Powers, P.T. 2001. Exploitation-related changes in the growth and reproduction of tilefish and the implications for the management of deepwater fisheries. American Fisheries Society Symposium, 25: 199-210.

Harris, P.J., Wyansi, D.M., White, D.B., Mikell, P.P. \& Eyo, P.B. 2007. Age, growth, and reproduction of greater amberjack off the southeastern US Atlantic coast. Transactions of the American Fisheries Society, 136(6):1534-1545. doi: 10.1577/T06-113.1

Hernández, A. \& Seijo, J.C. 2003. Spatial distribution analysis of red grouper (Epinephelus morio) fishery in Yucatan, Mexico. Fisheries Research, 63: 135-141.

Hoose, H.O. \& Moore, R.H. 1977. Fishes of the Gulf of Mexico. Texas, Louisiana, and adjacent waters (claves). Texas A \& M University, Texas.

Hyder, K., Weltersbach, M.S., Armstrong, M., Ferter, K., Townhill, B., Ahvonen, A., et al. 2018. Recreational sea fishing in Europe in a global context-Participation rates, fishing effort, expenditure, and implications for monitoring and assessment. Fish and Fisheries, 19(2): 225-243.

Ihde, T.F., Wilberg, M.J., Loewensteiner, D.A., Secor, D.H. \& Miller, T.J. 2011. The increasing importance of marine recreational fishing in the US: challenges for management. Fisheries Research, 108: 268-276.

Kožul, V., Skaramuca, B., Glamuzina, B., Clavic, N. \& Tutman, P. 2001. Comparative gonadogenesis and hormonal induction of spawning of cultured and wild Mediterranean amberjack (Seriola dumerili Risso 1810). Scientia Marina, 65: 215-220.

Lewin, W.C., Arlinghaus, R. \& Mehner, T. 2006. Documented and potential biological impacts of recreational fishing. Insights for management and conservation. Reviews in Fisheries Science, 14: $305-$ 367.

Lloret, J., Zaragoza, N., Caballero, D. \& Riera, V. 2008. Biological and socioeconomic implications of recreational boat fishing for the management of fishery resources in the marine reserve of Cap de Creus (NW Mediterranean). Fisheries Research, 91: 252-259.

López-Rocha, J.A. \& Arreguín-Sánchez, F. 2008. Spatial distribution of red grouper Epinephelus morio catchability on the Campeche Bank of Mexico. Journal of Applied Ichthyology, 24: 282-289.

López-Rocha, J.A. \& Arreguín-Sánchez, F. 2013. Spatial dynamics of the red grouper Epinephelus morio on the Campeche Bank, Gulf of Mexico. Scientia Marina, 77: 313-322. 
McPhee, D.P., Leadbitter, D. \& Skilletter, G.A. 2002. Swallowing the bait: is recreational fishing in Australia ecologically sustainable? Pacific Conservation Biology, 8: 40- 51.

Mexicano-Cíntora, G. 1999. Crecimiento del pargo canane Ocyurus chrysurus (Bloch, 1791) de la costa norte de Yucatán, México. Proceedings of the Gulf and Caribbean Fisheries Institute, 45: 338-348.

Monroy-García, C., Galindo-Cortes, G. \& HernandezFlores, Á. 2014. Mero Epinephelus morio, en la Península de Yucatán. In: Beléndez-Moreno, L.F., Espino-Barr, E., Galindo-Cortés, G., Gaspar-Dillanes, M.T., Huidobro-Campos, L. \& Morales-Bojórquez, E. (Eds.). Sustentabilidad y pesca responsable en México. Evaluación y manejo. INAPESCA-SAGARPA, Ciudad de México, pp. 243-278.

Muller, R.G., Murphy, M.D., Silva, J. \& Barbier, L.R. 2003. A stock assessment of yellowtail snapper, Ocyurus chrysurus, in the southeast United States. Final report submitted to the National Marine Fisheries Service, the Gulf of Mexico Fishery Management Council, and the South Atlantic Fishery Management Council as part of Southeast Data, Assessment, and Review (SEDAR) III, 239 pp.

National Marine Fisheries Service (NMFS). 2010. Marine recreational information program. [www.st.nmfs.noaa. gov/mrip/aboutus/timeline.html]. Reviewed: March 30, 2020.

Neter, J., Kutner, M.H., Wasserman, W. \& Nachtschien, J. 1996. Applied linear statistical models. McGrawHill/Irwin, Chicago.

Pitcher, T.J. \& Hollingworth, C.E. 2002. Fishing for fun: where's the catch? In: Pitcher, T.J. \& Hollingworth, C.S. (Eds.). Recreational fisheries: ecological, economic, and social evaluation. Blackwell Science, Oxford.

Piñeiro, R. \& Giménez, E. 2001. Características térmicas del Banco de Campeche. Ciencia Pesquera, 15: 83-87.

Received: 6 August 2019; Accepted: 10 May 2020
Pita, P., Alós, J., Antelo, M., Artetxe, I., BitonPorsmoguer, S., Carreño, A., et al. 2020. Assessing knowledge gaps and management needs to cope with barriers for environmental, economic, and social sustainability of marine recreational fisheries: the case of Spain. Frontiers in Marine Science, 7. doi: 10.3389/fmars.2020.00023

Poot-López, G., Rubio-Bueno, S., Villegas-Hernandez, H., Gonzales-Salas, C., Guillen-Hernandez, S. \& DíazGamboa, R.E. 2018. Catch composition, effort, and selectivity of fishes of recreational fishing in Yucatán, Mexico. Global Journal of Science Frontier Research: Interdisciplinary, 18(1): $11 \mathrm{pp}$.

Steinback, S., Gentner, B. \& Castle, J. 2004. The economic importance of marine angler expenditures in the United States. NOAA Professional Paper NMFS, 2: $169 \mathrm{pp}$.

Then, A.Y., Hoenig, J.M., Hall, N.G. \& Hewitt, D.A. 2015. Evaluating the predictive performance of empirical estimators of natural mortality rate using information on over 200 fish species. ICES Journal of Marine Science, 72: 82-92.

Torres-Lara, R. \& Salas-Márquez, S. 1990. Crecimiento y mortalidad de la rubia Lutjanus synagris de las costas de Yucatán durante las temporadas de pesca 19831985. Anales del Instituto de Ciencias del Mar y Limnología, 17(2): 205-214.

Tunca, S., Ünal, V., Miran, B., Güçlüsoy, H. \& Gordoa, A. 2016. Biosocioeconomic analysis of marine recreational fisheries: a comparative case study from the eastern Mediterranean, Turkey. Fisheries Research, 174: 270-279.

Vidal-Hernández, L., Bravo-Calderón, A. \& LópezRocha, J. A. 2017. Evaluación del impacto de la pesca deportiva en seis especies de peces en Yucatán, México, mediante indicadores basados en tallas. Proceedings of Gulf and Caribbean Fisheries Institute, 69: 297-305.

Wolf-Christian, L., Arlinghaus, R. \& Mehner, T. 2006. Documented and potential biological impacts of recreational fishing: insights for management and conservation. Reviews in Fisheries Science, 14: 305367. 